\title{
Vibrant with Words and The Colour of Distance
}

\section{Reviewed by Nicola Chapman.}

Vibrant with Words: the Letters of Ursula Bethell. Ed. Peter Whiteford. Wellington: Victoria University Press, 2005.

The Colour of Distance: New Zealand writers in France / French Writers in New Zealand. Eds. Jenny Bornholdt and Greg O'Brien. Wellington: Victoria University Press, 2005.

These otherwise two very different books have one important thing in common - both are part of the discussion, over time, between different people and cultures - about what it means to live, and create, in New Zealand.

Mary Ursula Bethell's poetry and friendships contributed a lot to this discussion in the 1930s and 40s. Her fresh and thoughtful poetry describing her beloved garden and the Canterbury landscape is still anthologised, but few now are aware of her influence on others. Charles Brasch was very grateful to her. In 1946, when canvassing material for the first edition of Landfall (a project which had been strongly supported by Bethell) he wrote to John Schroder: 'Miss Bethell was a friend - \& guide \& philosopher - to so many of the young \& aspiring in so many fields, \& also to others not so young, that any future social historian of this period will be bound to regard her as an important figure...' ( $p$. $\mathrm{x})$. This book helps us to understand why.

Bethell's lively letters are made still more accessible by Peter Whiteford's helpful introduction, notes, bibliography and indexing. This book will be invaluable not only for those interested in Bethell's poetry, but also in the developing work of writers, artists, and critics from the 1930s onwards, such as Toss Woollaston, Charles Brasch, Eric McCormick, Monte Holcroft and Rodney Kennedy.

The book, however, is more than a useful cultural record. It is powerful drama. Bethell was a complex person - a well-educated and cultured Victorian lady who devoted herself to social work; a devout Anglican who struggled for religious peace all her life; and a proclaimed Anglophile with a strong distaste for most common colonials but whose writings revel in the New Zealand landscape and who was kind to any needy or worthily aspiring person. 
Few letters remain from Bethell's life before she became a published poet in 1929. However those few still give a strong impression of the author's early personality and era. They describe her life with the cultured Mayhew family in London, her education, and her social work, and give unusual glimpses of the Victorian age, such as when she describes her Swiss finishing school: 'But enough of my teeth. I will turn to fleas... Scarcely a night passes that I do not have a grand hunt.' (p. 10). The letters from her social work period show an agonised awareness of the clash between her idealism and her intolerance. She likes working with the underprivileged, but not her good Anglican sisters: 'What is the use of trying to be a parish worker \& love your parishioners when you hate your house companions to distraction...those tiresome untidy feckless old Greyladies...' (p. 27).

The letters from 1929 onwards begin in a period of happiness and creativity. In 1924 Bethell had built a cottage on the Cashmere hills, Christchurch, and lived there with her dear friend Effie Pollen until Effie's sudden death in 1934. As she explains to Eileen Duggan her poetry was written in that decade's 'burst of excitement - of joy.' (p. 137). But after Effie's death, she describes herself as a 'tree struck by lightning - dead. I can think things, but not feel them - One must feel to write - All joy is lost.' (p. 138).

Bethell completes only memorial poems after Effie's death, but she writes many letters, especially to young men with artistic and literary ambitions. In encouraging their talents and spirituality, she advises, lends books, discusses issues, and is intensely, warmly, interested in their lives. The young John Summers is even advised on managing his sexuality: 'Don't listen to Strauss, Johnny, that's bad, that's weakening...always choose what is bracing...' ( $p$. 218). (In fairness to Bethell, Summers had been candid and lengthy on matters sexual and spiritual in his letters to her.)

If Bethell can be a tad over-maternal, she can also be open and vulnerable. One of the most interesting and moving letters is an autobiographical one written to Charles Brasch in England in 1941. Brasch had written 'some of my generation have never known a stable world' and Bethell responds with a fascinating autobiographical account of how she had responded to the great movements of her generation, her unhappy relationship with her mother, inner peace, the difficulties of pacifism during the current war, religious faith, and her awareness of social injustices gained from working in the slums 'I remember the boys' argument that Christianity was impossible for them because everyone outside their own families was an enemy (competing for their jobs)...' (p. 255).

Bethell's ongoing struggle for peace and relief from loneliness reaches a climax 
the year before she dies, when the marriage of her new young friend Kathleen Taylor brings 'a shattering revelation of what I had missed in life...' (p. 306). She records her mental anguish and physical pain in an astonishingly intimate set of diary-letters to the honeymooning couple. Her last few letters do show composure, although she almost seems to welcome the news of her terminal illness. She continues to write letters while she can - encouraging Brasch to return to New Zealand 'Come back \& do your best for this cut off little country' (p. 336) - farewelling friends, advising on a new edition of her previous books, and working on a sequence of poems about her childhood by the River Ashley.

For much of her adult life, Bethell considered herself English, not a New Zealander. Yet in her writings, the River Ashley and Mt Grey are her river and her mountain, and the song of the riro her personal song of joy. She gave much to this country, and in return belonged more deeply to it than perhaps she realised.

The Colour of Distance is Janet Frame's description of how distance can give insight into the familiar (in this case, Menton and Blenheim). It's a good title, as many of the writers in the book seem to have rose tints on their insightful spectacles - for the New Zealanders especially, the warm light of Mediterranean France. And even the French writers, although perhaps less enamoured of the New Zealand climate, write in a playful or reflective holiday mode.

However, this book was compiled for a serious reason: to mark 60 years of diplomatic relations between France and New Zealand (1945 to 2005). All the material (journals, poems, excerpts from novels, photographs, comic strip), apart from the inescapable Katherine Mansfield pieces, comes from within that period. This time-frame, and the ongoing French connection of the Katherine Mansfield Memorial Fellowship in Menton, allows the editors to include excerpts from nearly all New Zealand's best writers. Their detailed and erudite (if slightly indigestible) introduction puts the French/New Zealand relationship into a wider historical context, and manages to squeeze in many more relevant names and creative activities.

A serious raison d'être does require some serious writing: rugby (along with KM) is a recurring theme. One of the highlights of the collection for me was Denis Lalanne's description of the 1961 rugby test between the All Blacks and the Tricolours in Wellington's most fiendish weather. This is the most violent encounter in the book, apart from the 1985 one mentioned only by the editors, and is a lovely mixture of Gallic romanticism and humour. (For DownUnder humour, read Michael King's description of an evening out with an 'exaltedly 
inebriated' Patrick White in a classy restaurant singing 'chansons ethnique du Sud Pacifique' - 'Click go the Shears' etc).

Other pieces are more meditative, such as Peter Bland's poem for Louis Johnson:

' 'Displacement,' you wrote, 'is a kind/of freedom...Let's count ourselves lucky/we don't belong!' ' ('A Last Note from Menton', p. 193). Both rugby and self-awareness are in the excerpt from Lloyd Jones' wonderful The Book of Fame: 'We liked the French/ We were surprised to discover that we liked the French/ We had an inkling that we were not supposed to/ ... History. It felt good to work yourself into that old story.' (pp. 73-4). Another meditative piece is Cilla McQueen's beautifully evocative AvignonSummer 1978 diary. Its celebration of life with Ralph Hotere and their daughter makes Katherine Mansfield's lonely Menton Journal more poignant still: 'Oh Life! Accept me - make me worthy teach me...The leaves move in the garden, the sky is pale, and I catch myself weeping. It is hard - it is hard to make a good death...' (December 1920, p. 173).

There are far fewer French writers than New Zealand ones represented here. This is not necessarily because the French have found New Zealand less glamorous than vice versa. The Menton sojourn has made it easier for many of the New Zealand writers to spend time in thought-provoking 'displacement'. However, since 2002 the Randell Cottage Fellowship in Wellington has brought French writers to New Zealand and should secure 'the future of this ongoing literary dialogue' (p. 11). I particularly enjoyed Nadine Ribault's touching, funny account of meeting Janet Frame (and discovering what Janet kept in her garden shed). If the contents of this book are only the fruits of the dialogue so far, we have much to look forward to. 